\begin{tabular}{cc}
\hline EEJ 11 (1) (2021) 56-70 \\
ENNES \\
English Education Journal $/ /$ journal.unnes.ac.id/sju/index.php/eej
\end{tabular}

\title{
The Effectiveness of Herringbone and SQ4R as Techniques in Teaching Reading Comprehension to Students with Visual and Auditory Learning Styles
}

\author{
Nurhidayat Nurhidayat ${ }^{1 凶}$, Suwandi Suwandi ${ }^{2}$ \\ 1. SMP Negeri 2 Sedong, Kab. Cirebon, Jawa Barat, Indonesia \\ 2. Universitas PGRI Semarang, Indonesia
}

\begin{tabular}{l}
\hline Article Info \\
\hline Article History: \\
Accepted 27 \\
September 2020 \\
Approved \\
07December 2020 \\
Published 15 March \\
2021 \\
\hline
\end{tabular}

Keywords:

Herringbone, SQ4R,

Reading

Comprehension,

Learning Styles

\begin{abstract}
Applying the effective teaching techniques to teach reading comprehension is a must in order to overcome students' obstacles in comprehending a texts. This study analyzes the effectiveness of Herringbone and SQ4R to teach reading comprehension to visual and auditory students at SMPN 2 Sedong. This study belongs to quantitative research with quasi-experimental design applying $2 \times 2$ factorial design with ANOVA. There are two classes chosen as samples; $8 \mathrm{~A}$ as the experimental class I and $8 \mathrm{G}$ as the experimental class II. This study reveals that there is no interaction among techniques, reading comprehension, and learning styles in teaching reading comprehension to the visual and auditory students. Herringbone and SQ4R are effective to teach reading comprehension to students with visual and auditory learning styles. Both visual and auditory students have an equal improvement treated with herringbone and SQ4R since there is no significant difference in the improvement between visual and auditory students in reading comprehension treated by herringbone and SQ4R. Conversely, both herringbone and SQ4R have an equal effectiveness to teach reading comprehension to the visual and auditory students since there is no significant difference of effectiveness between herringbone and SQ4R to the visual and auditory students.
\end{abstract}

$\triangle$ Correspondence Address:

p-ISSN 2087-0108

J1. Irigasi No. 2, Sedonglor, Kec. Sedong, Kab. Cirebon, Jawa Barat,

e-ISSN 2502-4566

45189, Indonesia

E-mail: nurhidayat0059@gmail.com 


\section{INTRODUCTION}

As a global language, English is spoken by between two and three billion people (Ur, 2010). As a result, it brings to the condition where it is used in various purposes not exception in academic sectors. Therefore, the direction of English Language Teaching should be in line with the needs of the global condition (Pratama \& Yuliati, 2016), including in teaching reading skill. In academic context, reading not only plays a vital role in the teaching and learning process at all academic stages (Finnochiaro, 1984 in Maemun et al., 2018), but it can also be useful mean to gain success (Nugroho et al., 2019). Therefore, in Indonesia, reading mastery determines whether students are able or not to upgrade themselves to the further academic degree. This statement is taken from a fact showing that reading section always dominates the portion of test items in computerized-based national examination (UNBK) particularly at junior high school.

Theoretically, reading is viewed as visual process of translating a letter symbol into spoken form through sequential thinking processes. The processes include recognizing words, literal comprehension, interpretation, critical and creative reading (Suwandi et al., 2017). Among these thinking skills, comprehension has a vital position because before trying to interpret and respond critically the content of the text, through comprehension, reader initially tries to explore beyond the words, and understand the ideas and the relationships between ideas conveyed in a text (Rosari \& Mujiyanto, 2016). Thereby, in the context of Indonesia, reading comprehension becomes a purposes of the teaching reading as foreign language since it aims to improve the skills of learners, who have been able to read in their first language (Cahyono \& Widiati, 2009). Surprisingly, comprehension is not only influenced by how reader recognizes visually words in a text, but the reader's individual differences such as learning style also takes a part on it.

Learning style is a concept that represents a profile of the individual's approach to learning, a blueprint of the habitual or preferred way the individual perceives, interacts with, and responds to the learning environment (Dornyei, 2015, p.108). Then, it can be one factor influencing students' reading comprehension ability and achievement (Untoro, 2016; Alharbi, 2015). Among the other its classification, Dornyei (2015, p.126) categorizes individual's sensory preferences to be visual, auditory, kinesthetic, and tactile (VAKT). Shortly, visual learners learn effectively through a visual channel, prefer reading tasks, and often utilize a colorful highlighting schemes to make certain information visually more salient. Differently, auditory learners absorb the information effectively through auditory input such as lectures or audiotapes and prefer to deliver material orally by engaging in discussions and group work. Further, different from these previous styles, kinesthetic learners learn most effectively through complete body experience that engages wholebody movement. Therefore, they require frequent breaks and become fidgety sitting motionless for an hours.

As it is previously known together about the issues related to the importance of reading skill and reading comprehension especially in Indonesia academic settings, the writer finds a dilemma when the result of the field-observation instead shows a contradiction. In the real English reading activity, the writer observed that students are mostly annoyed dealing with reading comprehension activities. It is because the reading passages are unfamiliar for them resulting to the difficulty they face in understanding information implied in each text's paragraphs. Then, this condition becomes worse when there is always conventional treatment repeatedly occurs without innovation during the classroom activities. It is also negatively added by the situation of teaching and learning process which is still textbook-oriented. As a result of this situation, it is difficult for students whose learning styles are different to achieve good score in reading comprehension. They become a lowachievers especially in dealing with computerized-based national examination 
$(U N B K)$ at junior high school level. Therefore, the presence of recent teaching technique is needed to innovate the existing reading comprehension teaching and learning activities. In this case, the writer promotes Herringbone and SQ4R techniques which have been empirically proven to be effective tackling students' problem especially in reading comprehension.

Herringbone is a kind of graphic organizers that is used especially to organize supporting details of various texts to the main ideas (McKnight, 2010, p.50). This technique employs visual diagram which presents how text's supporting details in a form of W-H questions who, what, when, where, why, and how are constructed and connected to the main idea of the text. Further, Herringbone technique has proven to be effective in supporting students comprehending various genre of texts such as recount text (Yusuf et al., 2016; Rafain et al., 2013; Silvia \& Susana, 2017) narrative text (Kurniawan \& Indrawati, 2016; Rahila \& Sakdiah, 2016; Sudarmanto, 2018; Ramadhani \& Harputra, 2016), descriptive text (Wahyudi, 2018). Besides, Herringbone is also effective for teaching reading comprehension to students with individual differences such as reading habits (Fitriyani et al., 2020; Rosyida \& Ghufron, 2018), and improves students' reading comprehension at all academic level; senior high school level (Handayani et al., 2016; Samuri, 2018), junior high school level (Ningrum \& Widyawati, 2015; Pambayuningsih, 2018), and higher-education level (Umraiti et al., 2019)

On the other side, SQ4R is defined as a six steps system (survey, question, read, record, recite, and review) having a function for reading and comprehending textbook chapters (Wong, 2009, p.216). SQ4R technique supports students to understand how the parts of a particular text fit together to construct the whole text. By completing each of its steps, students also can distinguish between important and less important pieces of information and how to group similar ideas together. Besides Herringbone, several studies are also found that SQ4R technique is effective in teaching reading comprehension to students at the various academic level such as at beginner/ elementary level (Başar \& Gürbüz,
2017; Simbolon \& Marbun, 2017; Runiatun et al., 2016), and university settings (Erlina, 2018; Beyreli \& Incirkus, 2018; Khusniyah et al., 2017).

Finally, as previously presented, both Herringbone technique and SQ4R technique are empirically examined by previous researchers to be effective in teaching reading comprehension at all educational stages. Therefore, inspired by this, the recent study is intended to use Herringbone and SQ4R to overcome the problems faced by the eighth-grade students whose learning styles are visual or auditory. Thus, the objectives of this research are to analyze; (1) the interaction among reading comprehension, teaching techniques, and learning styles in reading comprehension, (2) the effectiveness of Herringbone to teach reading comprehension to visual students, (3) the effectiveness of Herringbone to teach reading comprehension to auditory students, (4) the effectiveness of SQ4R to teach reading comprehension to visual students, (5) the effectiveness of SQ4R to teach reading comprehension to auditory students, (6) the significant difference between the use of Herringbone to teach reading comprehension to visual and auditory students, (7) the significant difference between the use of SQ4R to teach reading comprehension to visual and auditory students, (8) the significant difference between the use of Herringbone and SQ4R to teach reading comprehension to visual students, and (9) the significant difference between the use of Herringbone and SQ4R to teach reading comprehension to auditory students.

\section{METHODS}

This research belonged to quantitative research with quasi-experimental design that applies 2x2 factorial design with a statistical analysis ANOVA (Analysis of Variance). Further, there were two groups involved, experimental group I (8G) treated by Herringbone and experimental group II (8F) treated by SQ4R. Then, the pre-test and post-test would be given to both of the groups. Related to the instruments, the researcher employed questionnaire, test, and observation sheet. Questionnaire was used to determine whether 
students categorized to have visual or auditory learning styles, pre-test was done to know students' achievement in reading comprehension before the treatments were given, post-test proposed to know whether Herringbone and SQ4R were effective or not to teach reading comprehension, and observation sheet plays as supporting instrument used to make sure that the process of treatments systematically goes on.

In collecting the data, there were 8 (eight) steps conducted; administering learning styles questionnaire, trying-out reading comprehension test to measure validity and reliability of the test items used, giving pre-test to both of experimental groups, giving treatment to experimental groups, utilizing observation sheet while giving treatment, giving post-test to both of experimental groups, analyzing the data collected by using SPSSv23, and interpreting the results of data analysis. To analyze the data, the whole process of quantitative data analysis was conducted by the assistance of SPSS v23. In this research, broadly, there were two statistical analyses applied by the researcher before and after administering test. Before giving test, there were validity, reliability and practicality tests. To measure the validity, Pearson Correlation statistical formula was applied while dealing with reliability, the researcher used Cronbach's Alpha. Then, after investigating the validity and reliability, the practicality test was conducted to make sure that the test is easily administered, as inexpensive as possible and its scores are easily interpreted. Moreover, after administering test, there were normality, homogeneity, T-test, and ANOVA tests. The normality was analyzed by using one-sample Shapiro-Wilk while to investigate the homogeneity of the data, Levene's for Homogeneity Variance was used. Furthermore, the two-way ANOVA was used to test whether the variables were interacted or not from one to the others and the T-tests with dependent and independent samples were used to analyze the result of pre-test and post-test in each groups.

\section{RESULTS AND DISCUSSION}

In this research, there were two classes of SMPN 2 Sedong, Kab. Cirebon chosen by the researcher as a sample. The experimental class I was class $8 \mathrm{~A}$ and experimental class II was class 8G. Moreover, two different treatments were given to those two classes. The experimental class I was treated by herringbone technique while experimental class II was treated by SQ4R technique. Initially, before giving treatments, the researcher distributed the questionnaire of VAKT learning style to categorize students' learning style into visual, auditory or kinesthetic. The questionnaire consisted of 30 multiple-choice questions which each choices represent three categories of behavior belonged to each learning styles. Based on the questionnaire's result, the researcher decided to take 15 visual students and 13 auditory students from experimental class I, while from experimental class II, 15 visual students and 12 auditory students were taken.

After that, the pre-test was given to those classes in order to measure the students' achievement especially in reading comprehension before given treatment. The pre-test was in a form of multiple-choices with 50 questions. The researcher allocated 120 minutes for students to conduct this test.

The next step was giving treatment to experimental class I using Herringbone technique and to experimental class II using SQ4R technique. There were 10 meetings of treatments given by the researcher to each experimental classes. During the treatments, the observation checklist that was constructed based on the theoretical procedures of teaching reading and implementing Herringbone technique and SQ4R technique in teaching reading comprehension was also employed. Actually, the observation checklist recorded all activities during the treatments. Thereby, by identifying the result of this, the researcher was able to monitor that the steps during treatments were systematically delivered. In this case, the treatments were received similarly by students in the experimental class 1 and experimental class 2 . The researcher had a similar teaching and learning activities and learning objectives that should be achieved by the 
students. The thing that makes difference was only students learning materials that were designed following the learning syntax belonged to Herringbone and SQ4R teaching techniques.

After receiving the treatments, the post-test was given to both of experimental groups. The post-test was used to know the students' reading ability after treated by Herringbone technique and SQ4R technique in their reading comprehension classes. Dealing with the test items, the items used in the post-test were actually similar to the pre-test given previously. The validity and reliability of the test items were also checked precisely in order to make sure that the items used were valid, reliable, and practical to be administered. The test items were also in a form of multiple-choice questions that consist of 50 numbers of reading comprehension test items. The time allocated for students to finish this test was also 120 minutes.

After obtaining the data, the data analysis was conducted. In this research, there were two statistical analysis that were conducted before and after administering test. Before giving test, there were tests of validity and reliability while after giving test, there were tests of normality, homogeneity, T-test, and ANOVA (Analysis of Variance). Particularly for tests of normality and homogeneity, those two statistical analysis were important to be conducted. Normality tests were done in order to make sure whether experimental class I and experimental class II had a normal distribution in their pre-test and post-test scores while homogeneity tests were proposed to check if both of the classes used as a samples in the research had a homogenous or similar prior ability in regards to their English reading comprehension. Dealing with the tests of normality, it was analyzed by using one-sample Shapiro-Wilk with the standard normality 0.05 . In this case, the distribution is normal, if sig (2tailed) $>0.05$. On the contrary, if sig (2-tailed) $<$ 0.05 , the distribution is not normal (Pratama, 2019:50). The result of Shapiro-Wilk in the pretest, in the experimental class I, the significant value of students with visual learning style was 0.20 . While for students with auditory learning style was 0.36 . On the other side, in the experimental class II, the significant value of students with visual learning style was 0.24 and significant value of students with auditory learning style was 0.15 . From this result it can be concluded that the pre-test scores in both of experimental class I and experimental class II were distributed normally. Moreover, the result of normality tests of the post-test scores, from this table, in the experimental class I, the significant value of students with visual learning style was 0.51 and with auditory learning style was 0.70 . On the other side, in the experimental class II, the significant value of students with visual learning style was 0.87 , and with auditory learning style was 0.75 . From this result, it can also be said that the post-test scores in both of the experimental class I and experimental class II in both of visual and auditory were also normally distributed.

Besides normality tests, homogeneity tests were also conducted after the scores of pre-test and post-test were obtained from the experimental class I and experimental class II and before the T-tests were conducted. The homogeneity tests were proposed to make sure if both of the classes used as a samples in the research had a homogenous or similar prior ability in regards to their English reading comprehension. Thus, if the data were not homogeneous, the treatment could not be applied because both of the classes did not have same ability in reading comprehension. To measure the homogeneity, the researcher used Levene's Test of Homogeneity of Variance. In this case, the data is considered to be homogeneous if sig (2tailed) $>0.05$ (Sundayana, 2005:167). Starting from the pre-test score, the result of the homogeneity test of the pre-test showed that the significant value for the homogeneity test of the pre-test was 0.31 , it means the data was homogeny because $0.31>0.05$. On the other side, result of the homogeneity test of the posttest revealed that the significant value for the homogeneity tests of the post-test was 0.20 . It means the data was also homogeny because 0.20 $>0.05$. Looking at these results, it can be concluded that the significant values of both pretest and post-test were higher than 0.05 . Therefore, the variance of the data in the pre-test and post-test were homogeneous. 
Furthermore, after knowing the results of normality and homogeneity tests, hypothesis testing was conducted to answer the research questions. The results of hypotheses testing are as follows.

\section{The Interaction among Techniques, Students' Learning Styles, and Reading Comprehension}

The first objective of this research was to analyze the interaction among techniques, students' learning styles, and reading comprehension. The result of statistical analysis presenting the interaction among techniques, students' reading comprehension, and students' different learning styles can be seen in Table 1 as follows.

Table 1. The result table of ANOVA test of achievement interaction among techniques, reading comprehension, and students' learning styles in teaching reading comprehension to students' with visual and auditory learning styles (Tests of Between-Subjects Effects) Tests of Between-Subjects Effects

Dependent Variable: reading_comprehension_achievement

\begin{tabular}{llllll}
\hline Source & $\begin{array}{l}\text { Type III } \\
\text { Squares }\end{array}$ & Sum & of & & \\
\hline Corrected Model & $632.940^{\mathrm{a}}$ & $\mathrm{df}$ & Mean Square & $\mathrm{F}$ & Sig. \\
Intercept & 250593.543 & 3 & 210.980 & .773 & .514 \\
techniques & 4.179 & 1 & 250593.543 & 918.732 & .000 \\
learningstyles & 294.108 & 1 & 4.179 & .015 & .902 \\
techniques & $*$ & 1 & 294.108 & 1.078 & .304 \\
learningstyles & 352.593 & 1 & 352.593 & 1.293 & .261 \\
Error & 13910.769 & 51 & 272.760 & & \\
Total & 269408.000 & 55 & & & \\
Corrected Total & 14543.709 & 54 & & & \\
\hline
\end{tabular}

a. R Squared $=, 044$ (Adjusted R Squared $=-, 013$ )

types, reading habit, background

The result of statistical analysis ANOVA (Analysis of Variance) showed that the significant value of techniques*learning styles was 0.261 . It was higher than 0.05 meaning that Ho was accepted and $\mathrm{Ha}$ was rejected. So, it indicated that there was no interaction among teaching techniques, reading comprehension, and students' learning style in teaching reading comprehension to the visual and auditory students. From this result it can be inferred that the students' reading comprehension improvement neither depends on the teaching techniques applied which were herringbone and SQ4R, nor their learning styles which were categorized to visual and auditory. Besides teaching techniques and learning style, there must be other variables influencing students' reading comprehension achievement. Those variables can be students' personality

knowledge, and their daily achievement at school.

According to the first hypothesis testing it can be known that there was no interaction among teaching techniques, reading comprehension, and students' learning styles. This result proves that although learning style becomes one important factor determining student's academic achievement, but it does not specifically relate to the improvement of reading comprehension (Erginer, 2014). On the other words, there is no significant correlation between learning style and students' reading comprehension (Pratiwi et al., 2013; Rachma et al., 2015). Additionally, this result also strengthens Maghfirah's research findings (2018) which revealed that learning style is not the only one factor affecting students' achievement of language's receptive skill. Students who receive 
treatments according to their learning styles do not mean that they will achieve a better score compared to them who do not (Garza, 2008).
The Effectiveness of Herringbone Technique to Teach Reading Comprehension to Students with Visual Learning Style

The second objective of this research was to analyze the effectiveness of herringbone technique to teach reading comprehension to students with visual learning style. The result was explained in Table 2.

Table 2. Paired Samples Test of Herringbone to Visual Students

Paired Samples Test

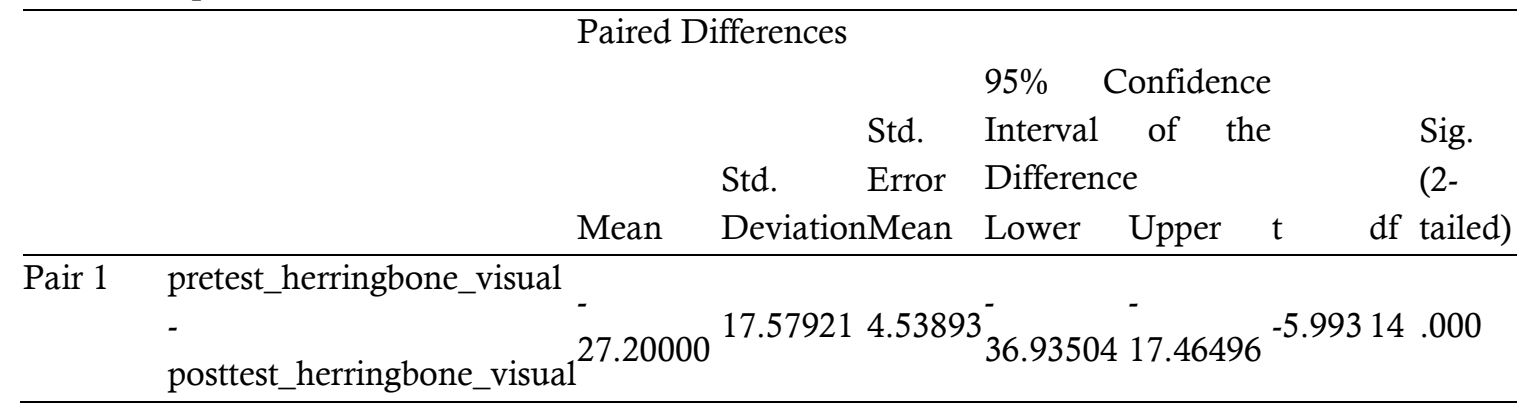

The result indicated that herringbone was practically effective to teach reading comprehension to visual students. This statement was based on the data shown that there was an improvement in the post-test score of the experimental class I after receiving the treatment. Actually, the mean score of post-test (76.866) was higher than the mean score of pretest (52.466). Furthermore, the result of paired samples t-test showed that the significance level was 0.00 . It indicated that $0.00<0.05$. Related to the hypothesis testing, this result indicated that Ho was rejected and $\mathrm{Ha}$ was accepted. Therefore, it means that there was a significant difference

Table 3. Paired Samples Test of Herringbone to Auditory Students Paired Samples Test between pre-test and post-test scores of students with visual learning style treated by using Herringbone technique in reading comprehension. On the other words, using herringbone technique was effective to enhance students' reading comprehension to visual learners in experimental class I.

The Effectiveness of Herringbone Technique to Teach Reading Comprehension to Students with Auditory Learning Style.

The third objective of this research was to analyze the effectiveness of Herringbone technique to teach reading comprehension to students with auditory learning style. The result was explained in Table 3.

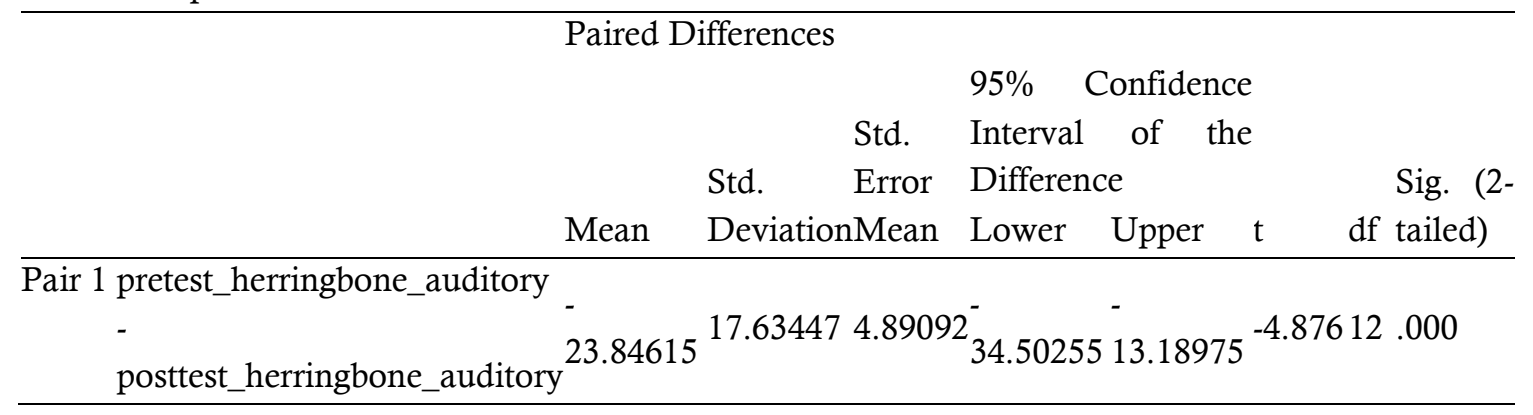


Based on the result, it also showed that herringbone was effective to teach reading comprehension to auditory students. This statement was based on the data showing that there was improvement score from the pre-test score to the post-test score. The means score of pre-test (44.461) was lower than mean score of post-test (68.307). Further, the results of paired samples t-test also showed that the significant value was 0.000 which it was lower than 0.05 . Related to the hypothesis testing, it indicated that Ho was rejected and $\mathrm{Ha}$ was accepted. Therefore, it can be interpreted that there was significant difference between pre-test and posttest scores of students with auditory learning style treated by using Herringbone technique in reading comprehension. It could also be said that using herringbone technique was effective to teach reading comprehension to students having auditory learning style.

Based on the second and third hypotheses testing, this study revealed that herringbone technique was effective to teach reading comprehension to students having both visual and auditory learning styles. It is in line with a research conducted by Yusuf et al., (2016), Rafain et al., (2013), Silvia \& Susana (2017),
Kurniawan \& Indrawati (2016), Rahila \& Sakdiah (2016), Sudarmanto (2018), Ramadhani \& Harputra (2016), Wahyudi (2018), Fitriyani et al., (2020), Rosyida \& Ghufron (2018), Handayani et al., (2016), Samuri (2018), Ningrum \& Widyawati (2015), Pambayuningsih (2018), and Umraiti et al., (2019). Moreover, this result also straightforwardly proved that graphemic diagram seems like a skeleton of herring fish belonged to herringbone technique can help students to identify texts' supporting details which finally lead them to find texts' main ideas. Further, the displays of a fish skeleton of herringbone technique during reading classroom also lead students' mind to imagine a fish carrying whole important features of the text. Thereby, it can help them to simply comprehend a particular reading text.

\section{The Effectiveness of SQ4R Technique to Teach Reading Comprehension to Students with Visual Learning Style}

The fourth objective of this research was to analyze the effectiveness of SQ4R technique to teach reading comprehension to students with visual learning style. The result was explained in Table 4.

Table 4. Paired Samples Test of SQ4R to Visual Students

Paired Samples Test

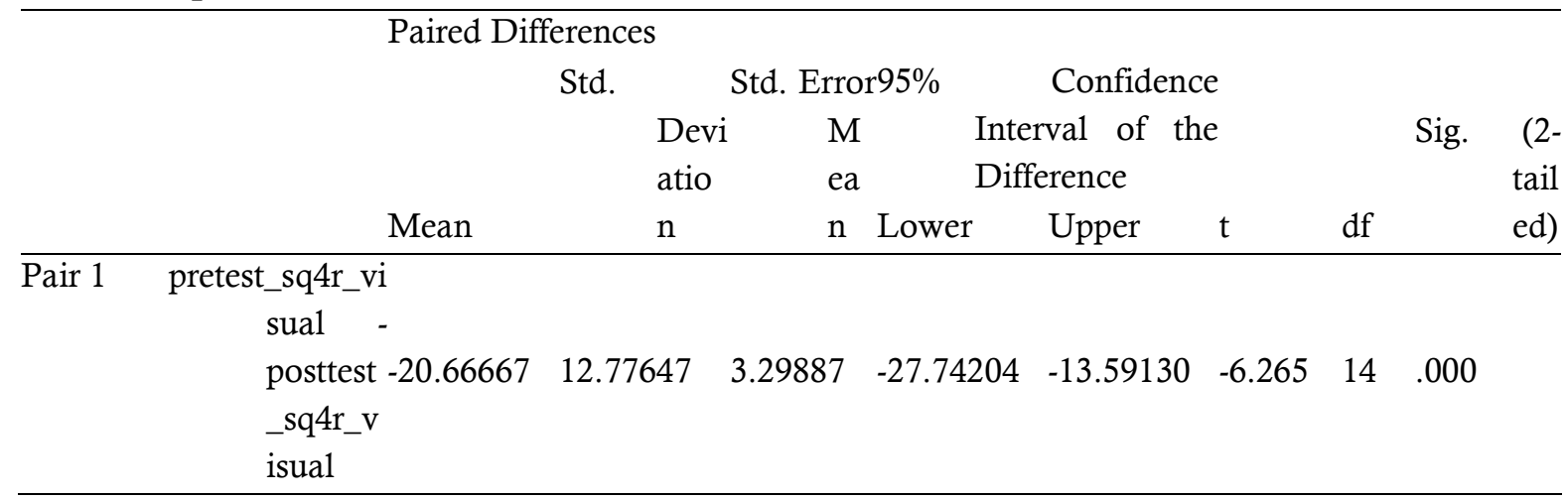

Then, the result showed that SQ4R was effective to teach reading comprehension to auditory students. This statement was based on the improvement score in pre-test to the post-test which the mean score of post-test (72.400) was higher than the mean score of pre-test (51.733). Further, the result of the paired samples t-test also showed that the significant value was 0.000 which it was lower than 0.05 . Related to the hypothesis testing, it indicated that Ho was rejected and the Hawas accepted. Therefore, it can be interpreted that there was significant difference between pre-test and post-test scores of students with visual learning style treated by using SQ4R technique in reading comprehension. On the other words, using 
SQ4R technique was effective to teach reading comprehension to students with visual learning style.
The Effectiveness of SQ4R Technique to Teach Reading Comprehension to Students with Auditory Learning Style.

The fifth objective of this research was to analyze the effectiveness of SQ4R technique to teach reading comprehension to students with auditory learning style. The result was explained in Table 5.

Table 5. Paired Samples Test of SQ4R to Auditory Students

Paired Samples Test

\begin{tabular}{|c|c|c|c|c|c|c|c|c|c|}
\hline & & Paired & ifferences & & & & & & \\
\hline & & & & & $95 \%$ & Confiden & & & \\
\hline & & & & Std. & Interval & of $\mathrm{t}$ & & & \\
\hline & & & Std. & Error & Difference & & & & Sig. $\quad(2-$ \\
\hline & & Mean & Deviation & n Mean & Lower & Upper & $\mathrm{t}$ & $\mathrm{df}$ & tailed) \\
\hline ir 1 & pretest_sq4r_auditory & & & & & & & & \\
\hline & - & -20.000 & 13.56466 & 3.9157 & -28.61857 & $7-11.3814$ & $3-5.108$ & 11 & .000 \\
\hline
\end{tabular}

The result showed that SQ4R was also effective to be used in teaching reading comprehension to auditory students. This statement was based on the data indicating that there was an improvement in the pre-test score to the post-test score. The mean score of pre-test (42.666) was lower than the mean score of posttest (62.666). Furthermore, the result of paired sample t-test also showed that the significant value was 0.000 . It can be analyzed that it was < 0.05 . So, related to the hypothesis testing, it means that $\mathrm{Ho}$ was rejected and $\mathrm{Ha}$ was accepted. Therefore, it can be interpreted that there was significant difference between pre-test and post-test scores of students with auditory learning style treated by using SQ4R technique in reading comprehension. On the other words, using $\mathrm{SQ} 4 \mathrm{R}$ technique was effective to teach reading comprehension to students with auditory learning style.

Moreover, based on the fourth and fifth hypotheses testing, it is known that SQ4R technique were effective to teach reading comprehension to visual and auditory students. This result also confirms positively the findings of studies conducted by Başar \& Gürbüz (2017), Simbolon
\& Marbun (2017), Runiatun et al., (2016), Erlina (2018), Beyreli \& Incirkus (2018), and Khusniyah et al., (2017). This result also confirms that the systematic steps of reading promoted by SQ4R technique also gives students solution to easily get their purpose in reading a texts. These steps give students opportunity to survey the text's features, to turn these text's features explored into questions, to select carefully and thoroughly the important materials can be worked to answer the created questions, to take notes the important information they have read previously, to skim back over a previous steps or sections, and to make sure that they comprehend the previously conducted steps that lead them to make the best habit.

\section{The Significant Difference between the Use of} Herringbone to Teach Reading Comprehension to Students with Visual and Auditory Learning Styles.

The sixth objective of this study was to analyze the significant difference between the use of herringbone to teach reading comprehension to students with visual and auditory learning styles. The result was explained in Table 6 . 
Table 6. Independent Samples Test of Herringbone Technique to Visual and Auditory Students in Reading Comprehension

Independent Samples Test

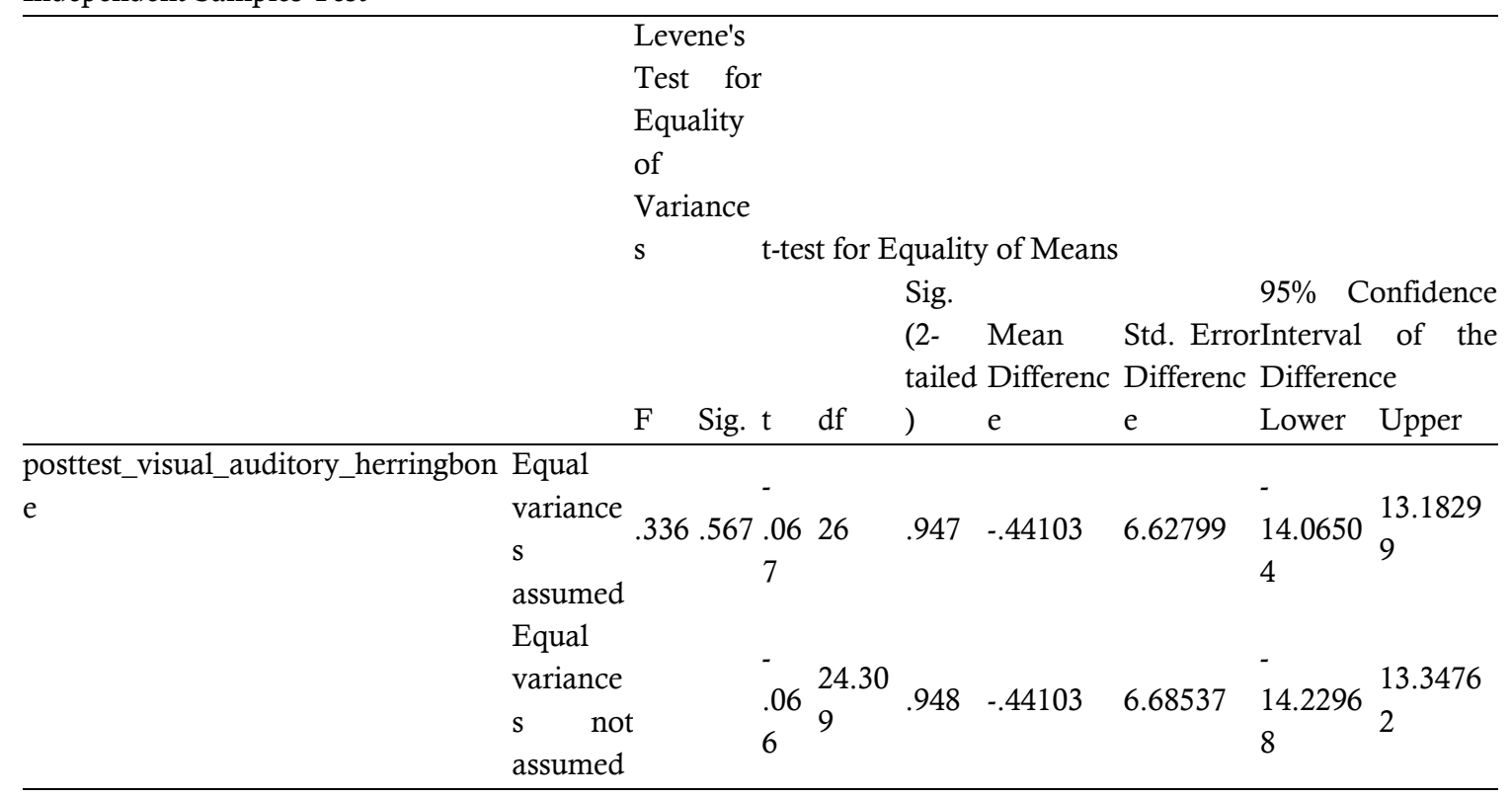

The result showed that, looking at the mean score, herringbone was more effective to teach reading comprehension to auditory students rather than visual students. This statement was supported by the mean score of the visual students (67.866) which was lower than the mean score of the auditory students (68.307). Furthermore, the result of the independent samples $t$-test showed that the significant level was 0.947 . It indicated that $0.947>0.05$. Related to the hypothesis testing, it indicated that Ho was accepted and $\mathrm{Ha}$ was rejected. It means that there was no significant difference between post-test score of students with visual and auditory learning style treated by using Herringbone technique in reading comprehension. On the other words, the visual and auditory students have an equal improvement treated with Herringbone techniques even though the mean score of the visual students is lower than the mean score of the auditory students.

The Significant Difference between the Use of SQ4R to Teach Reading Comprehension to Visual and Auditory Students

The seventh objective of this study was to analyze the significant difference between the use of SQ4R to teach reading comprehension to visual and auditory students. The result was $\begin{array}{llll}\text { explained } & \text { in } & \text { Table } & 7 .\end{array}$ 
Table 7. Independent Samples Test of SQ4R Technique to Visual and Auditory Students in Reading Comprehension

Independent Samples Test

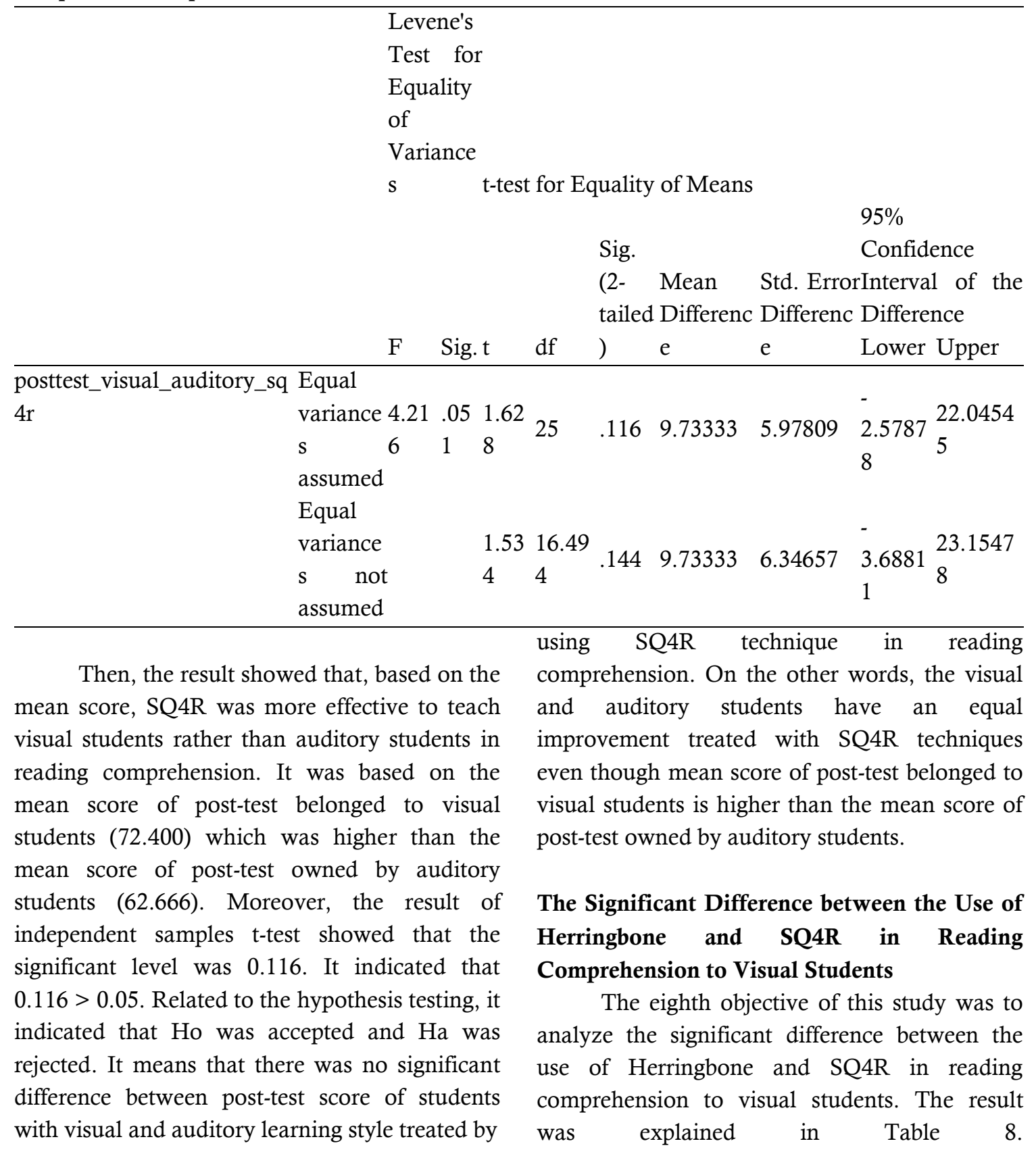


Table 8. Independent Samples Test of Herringbone and SQ4R Techniques to Visual Students in Reading Comprehension

Independent Samples Test

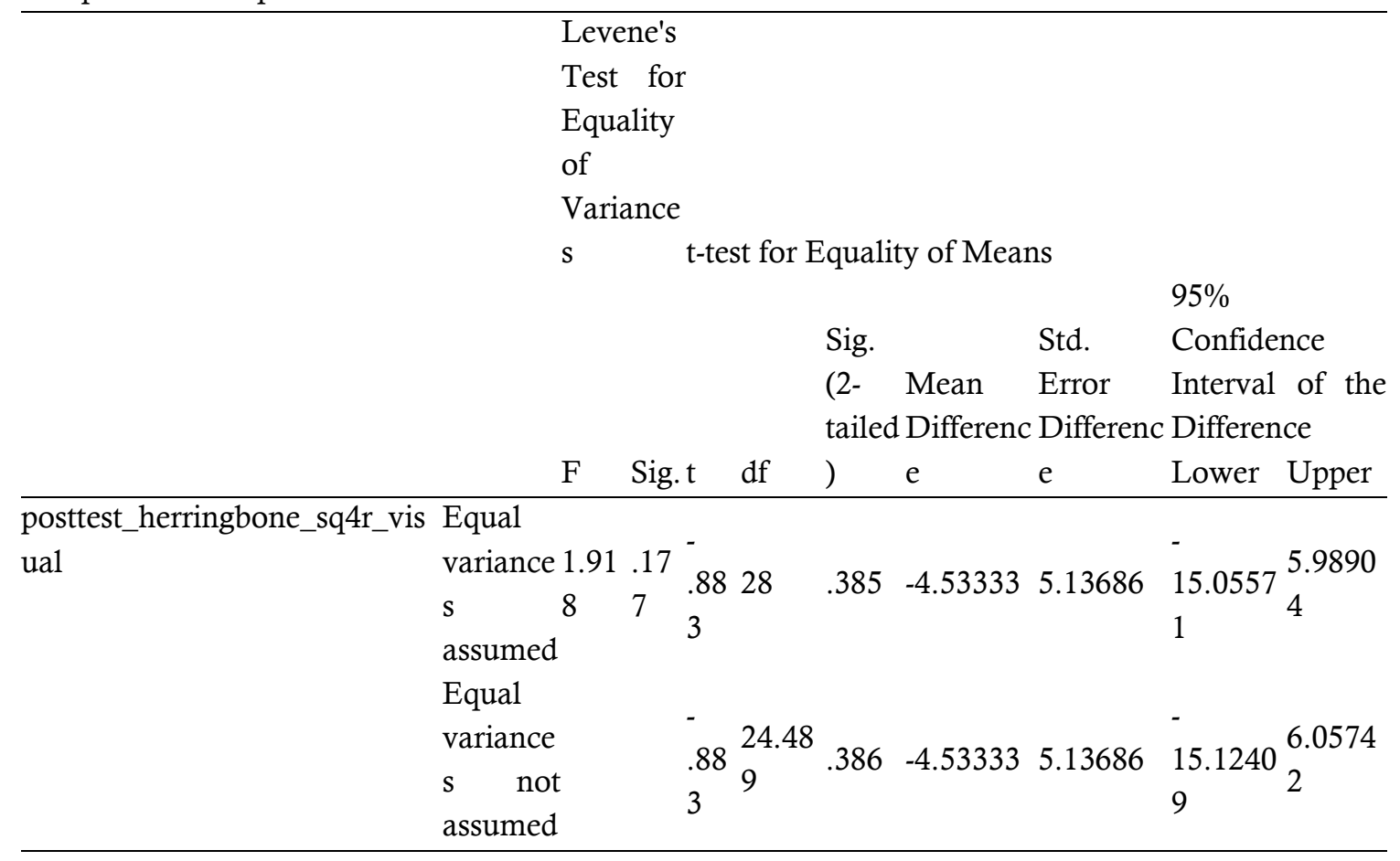

The result revealed that, looking at the mean score, SQ4R was more effective than herringbone in reading comprehension to visual students. It was based on the visual students' means score of post-test in experimental class II (72.400) was higher than the means score of post-test in the experimental class I (67.866). Further, the result of the independent samples ttest showed that the significant level was 0.385 . Related to the hypothesis testing, it indicated that $0.385>0.05$. Therefore, Ho was accepted and $\mathrm{Ha}$ was rejected. Thus, it can be said that there was no significant difference between posttest score of students with visual learning style treated by using Herringbone technique and SQ4R technique in reading comprehension. On the other words, the use of Herringbone and SQ4R techniques have an equal effectiveness in teaching reading comprehension to the visual students even though the visual students' means score of post-test in experimental class II which is taught by SQ4R technique is higher than the means score of post-test in the experimental class I which is taught by Herringbone technique.

\section{The Significant Difference between the Use of Herringbone and SQ4R in Reading Comprehension to Auditory Students}

The nineth objective of this study was to analyze the significant difference between the use of Herringbone and SQ4R in reading comprehension to auditory students. The result was explained in Table 9. 
Table 9. Independent Samples Test of Herringbone and SQ4R Techniques to Auditory Students in Reading Comprehension Independent Samples Test

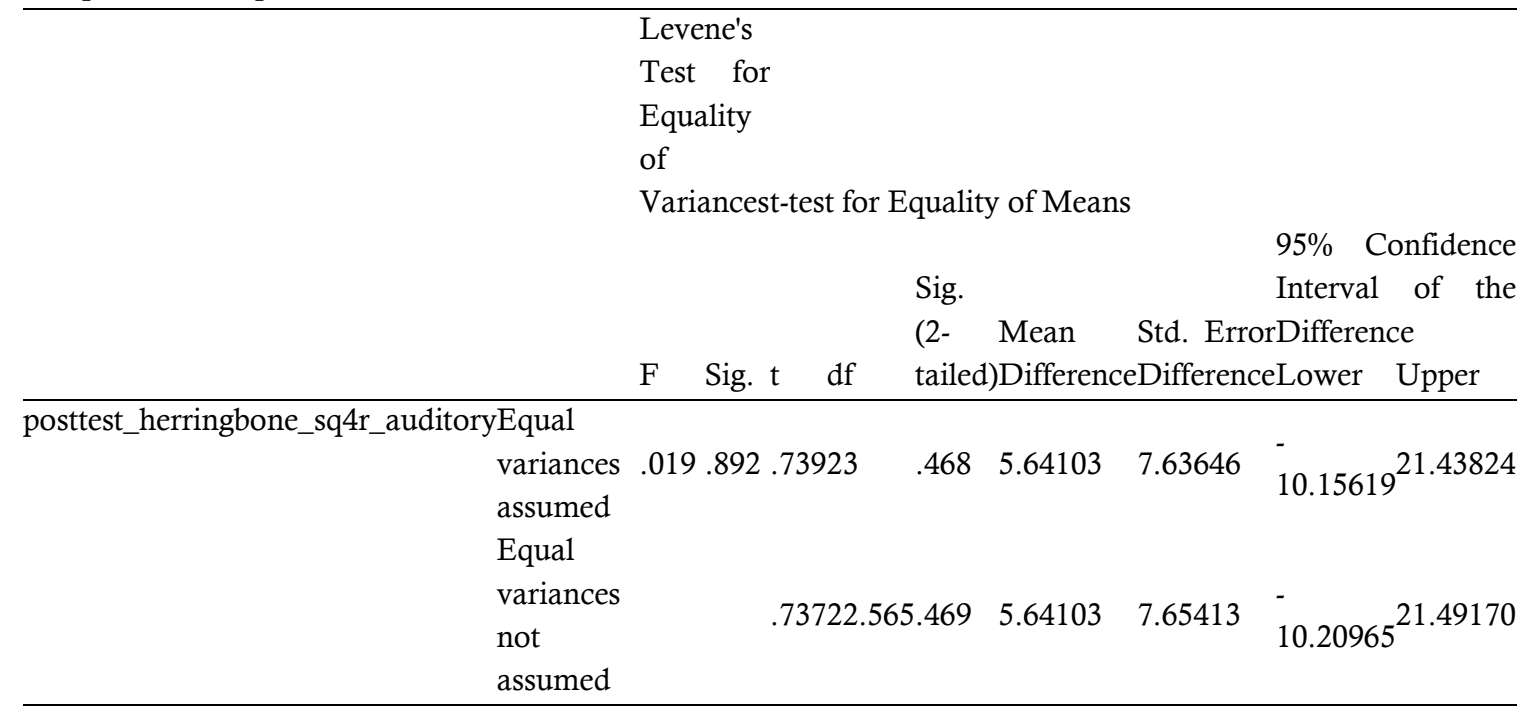

Then, the result showed that, based on the mean score, the use of herringbone was more effective than SQ4R in teaching reading comprehension to auditory students. This statement was based on the mean score of posttest in the experimental class I (68.307) which was higher than the mean score of post-test in the experimental class II (62.666). Moreover, the independent samples $t$-test resulted that significant value was 0.468 . Dealing with hypothesis testing, it indicated that $0.468>0.05$. Therefore, $\mathrm{Ho}$ was accepted and $\mathrm{Ha}$ was rejected. It means that there was no significant difference between post-test score of students with auditory learning style treated by using Herringbone technique and SQ4R technique in reading comprehension. On the other words, the use of Herringbone and SQ4R techniques have an equal effectiveness in teaching reading comprehension to the auditory students even though the mean score of post-test in the experimental class I which is taught by Herringbone technique is higher than the mean score of post-test in the experimental class II which is taught by SQ4R technique.

From the sixth, seventh, eighth, and nineth hypotheses testing it can be inferred that both visual and auditory students had equal improvement treated with herringbone and SQ4R techniques since there is no significant difference in the improvement between visual and auditory students in reading comprehension treated by herringbone and SQ4R techniques. Additionally, both herringbone and SQ4R techniques had equal effectiveness to teach reading comprehension to the visual and auditory students since there is no significant difference of effectiveness between herringbone and SQ4R techniques to the visual and auditory students.

\section{CONCLUSION}

This study focuses on comparing two teaching techniques namely Herringbone and SQ4R for teaching reading comprehension at the eighth-grade students of SMP Negeri 2 Sedong particularly to them having visual and auditory learning style. Findings of the study showed that even though there is no interaction among teaching techniques, reading comprehension, and students' learning styles, herringbone technique and SQ4R technique were proven to be effective to teach reading comprehension to students with different learning styles (visual and auditory). In addition, those two teaching techniques also had an equal effectiveness to teach reading comprehension to the visual and auditory students since there is no significant difference of effectiveness between herringbone and SQ4R techniques to the visual and auditory students. 


\section{REFERENCES}

Alharbi, M. A. (2015). Reading strategies, learning styles and reading comprehension: a correlation study. Journal of Language Teaching and Research, 6(6), 1257.

Başar, M., \& Gürbüz, M. (2017). Effect of the SQ4R technique on the reading comprehension of elementary school 4th grade elementary school students. International Journal of Instruction, 10(2), 131-144.

Beyreli, L., \& Incirkus, A. (2018). The effect of interactive read aloud and SQ4R reading strategies on comprehension: mixed method research. International Journal of Languages' Education and Teaching (IJLET), 6(1), 271-291.

Cahyono, B. Y., \& Widiati, U. (2009). The teaching of EFL listening in the Indonesian context: the state of the art. TEFLIN Journal, 20(2), 36-58.

Dornyei, Z. (2015). The Psychology of the Language Learner Revisited. Routledge.

Erlina, N. (2018). The increase of students' Arabic reading skills through the application of SQ4R learning technique. International Journal of Language Education and Culture Review, 4(1), 3757.

Fitriyani, N., Suwandi, \& Sutopo, D. (2020). The effectiveness of herringbone and buzz group techniques to teach reading comprehension for students with high and low reading habits. English Education Journal (EEJ), 10(3), 331-339.

Handayani, R., Tasnim, Z., \& Santihastuti, A. (2016). The effect of using herringbone technique on the eleventh grade students' reading comprehension achievement at SMAN 1 Pesanggaran. EFL Education Journal, 3(7), 529-538.

Khusniyah, N. L., Rasyid, Y., \& Lustyantie, N. (2017). Improving English reading comprehension ability through survey, questions, read, record, recite, review strategy (SQ4R). English Language
Teaching, $\quad 10(12), \quad 202-211$. https://doi.org/10.5539/elt.v10n12p202

Kurniawan, A. Y., \& Indrawati. (2016). The effectiveness of herringbone technique to teach reading of narrative text. Journal of English Language Teaching, 5(2), 1-10.

Maemun, A., Fitriati, S. W., \& Farida, A. N. (2018). The effectiveness of listen-readdiscuss (LRD) and graphic organizer combination technique to teach reading comprehension of descriptive text. Journal of English Language Teaching, ELT Forum, 7(2), 47-53.

McKnight, K. S. (2010). The Teacher's Big Book of Graphic Organizers 100 Reproducible Organizers that Help Kids with Reading, Writing, and the Content Areas. Pearson Education.

Ningrum, A. S. B., \& Widyawati, I. (2015). Improving students' reading comprehension skill using herringbone technique at MTS Al-Fatah Badas. INFERENSI: Journal Penelitian Sosial Keagamaan, 9(2), 397-416.

Nugroho, T., Anggani, D., \& Hartono, R. (2019). English teachers' perception on strategies in teaching reading comprehension to motivate the students. English Education Journal (EEJ), 9(77), 56-61.

Pambayuningsih, W. (2018). The effect of herringbone technique on the student's reading skill at 8 th grade junior high school. Getsempena English Education Journal (GEEJ), 5(1 Mei), 40-45.

Pratama, H. (2019). Statistika pada Bidang Pendidikan Bahasa. UNNES Press.

Pratama, H., \& Yuliati. (2016). Global education in English classroom: integrating global issues into English language teaching. International Journal of Social Science and Humanity, 6(9), 719-722.

Rafain, D., Zainuddin, A., \& Tiarina, Y. (2013). The effect of herringbone technique on students' reading comprehension in recount text at second grade of SMPN 2 Enam Lingkung Padang Pariaman. 
Rahila, C. D. I., \& Sakdiah, H. (2016). The effectiveness of herringbone technique to enhance students' ability in comprehending narrative text of the eighth grade students at MTSN Takengon II, Aceh Tengah, Aceh. INOVISH JOURNAL, 1(2), 1-10.

Ramadhani, Y. R., \& Harputra, Y. (2016). A comparative study between teaching reading comprehension of narrative text by using the herringbone technique (HT) and the context clues strategy to the eighth grade students of SMP Negeri 3 Padangsidimpuan in 2011-2012 academic year. International Journal of Research \& Method in Education, 6(2), 1-5.

Rosari, L., \& Mujiyanto, J. (2016). The effectiveness of know-want-learned and collaborative strategic reading strategies to teach reading comprehension to students with positive and negative attitudes. Engish Education Journal, 6(2), 33-41.

Rosyida, F., \& Ghufron, M. A. (2018). Herringbone and tri focus steve snyder technique: the techniques for teaching reading comprehension viewed from students' reading habit. International Journal of Instruction, 11(3), 603-616.

Runiatun, Istiyati, S., Matsuri, \& Sriyanto, M. I. (2016). Penggunaan strategi SQ4R (survey, question, read, reflect, recite, review) untuk meningkatkan keterampilan membaca pemahaman. Pgsdsolo, 1-6.

Samuri, R. (2018). Improving reading comprehension through herringbone technique to the eleventh grade students of SMA LTI-IGM Palembang. Jurnal Ilmiah Bina Bahasa, 11(1), 32-41.

Silvia, D., \& Susana, D. (2017). The use of herringbone technique in comprehending recount text at the tenth grade students of Madrasah Aliyah Terpadu Duri. AlIshlah: Jurnal Pendidikan, 9(2), 52-79.

Simbolon, N., \& Marbun, I. (2017). Implementation of SQ4R model to increase reading comprehension ability of elementary students. Advances in Social Science, Education and Humanities Research, 118(6), 999-1003.

Sudarmanto. (2018). Using herringbone technique in teaching reading narrative text at the eighth grade students of SMP Negeri 9 Parepare. EDUVELOP, 1(2), 76-85.

Sundayana, R. (2005). Statistika Penelitian Pendidikan. Alfabeta.

Suwandi, S., Sri Wahyuni, S. W., \& Sophia B, T. C. (2017). Reading comprehension: a guide for non-English lecturers at higher education in central java, Indonesia. SSRN Electronic Journal, 6(4), 336-344.

Umraiti, I., Usman, B., \& Samad, I. A. (2019). Using herringbone graphic organizer strategy to enhance students' reading comprehension. English Education Journal (EEJ), 10(3), 260-275.

Untoro, B. (2016). The effect of group investigation and learning style on students' writing of analytical exposition. IJEE (Indonesian Journal of English Education), 3(1), 29-45.

Ur, P. (2010). English as a lingua franca: a teacher's perspective. Cadernos de Letras (UFRJ), 27(December), 86-92.

Wahyudi, M. A. (2018). The effectiveness of herringbone strategy to descriptive texts at seventh grade students of SMAN 4 Bangkalan. SELL Journal, 3(2), 154-160.

Wong, L. (2009). Essential Study Skills 6th edition (Sixth Edit). Houghton Mifflin Company.

Yusuf, Y. Q., Fajrina, D., \& Sari, I. (2016). Developing the EFL students' reading comprehension by employing herringbone technique. Al-Ta'Lim Journal, 23(3), 183-190. 